Syntax Fusion : Jurnal Nasional Indonesia

p-ISSN: -

e-ISSN : 2775-4440

Vol. 1, No. 8, Agustus 2021

\title{
EVALUASI MANAJEMEN RISIKO TEKNOLOGI INFORMASI PADA M- BANKING BNI CABANG PENAJAM MENGGUNAKAN COBIT 5
}

\author{
Ayu Sri Wahyuni dan Darlinda
}

STMIK Borneo Internasional Balikpapan

Email: ayu_sri_wahyuni.18@stmik-borneo.ac.id, darlinda.18@stmik-borneo.ac.id,

\begin{abstract}
Abstrak
Bank Negara Indonesia (BNI) Cabang Penajam adalah sebuah institusi bank milik pemerintah, BNI merupakan sebuah lembaga keuangan yang memiliki pelayanan serta memfasilitasi perihal keuangan masyarakat dalam skala mikro. Pada Bank BRI teknologi informasi yang ada sudah memiliki SOP (Standar Operasional Prosedur), namun masih terdapat masalah dalam sistem maupun human error. Hal-hal yang dapat menyebabkan sebuah risiko yang apabila telah dibiarkan terus-menerus akan berakibat fatal pada perusahaan dan menghambat proses bisnis. Oleh karena itu maka sangat diperlukan adanya evaluasi pengelolaan risiko Teknologi Informasi (TI). COBIT 5 merupakan salah satu framework tata kelola TI yang terdiri dari 37 proses tata kelola yang dimuat dalam empat domain tatakelola TI yaitu Evaluate, Direct, Monitor (EDM), Align, Plain, Organise (APO), Build, Acquire, Implement (BAI) dan Monitor, Evaluate, Assess (MEI). Fokus pada penelitian ini adalah pengelolaan risiko TI (APO12) dalam framework COBIT 5. Tujuan penelitian yaitu untuk mengetahui tingkat kapabilitas serta strategi perbaikan untuk proses pengelolaan risiko. Dari hasil analisis penghitungan tingkat kapabilitas berada pada level 1 (Performed Process) dengan status Largely Achieved sebesar 79,10\% dengan demikian status tersebut telah memiliki bukti dan juga pendekatan secara sistematis dan pada pencapaian ini secara signifikan yang diperoleh melalui penilaian terhadap proses atribut. Target level yang ingin dicapai adalah 2 serta Rekomendasi agar level 1 ini mencapai fully achieved.
\end{abstract}

Kata Kunci: APO12, COBIT 5, EDM03, Pengelolaan Risiko, dan Teknologi Informasi

\section{Pendahuluan}

Pemanfaatan teknologi informasi tentunya sangat efektif dan efisien untuk menyelesaikan sebuah pekerjaan. Pemanfaatan pada penggunaan TI yang dapat meningkatkan kecepatan dan ketepatan infromasi data, dan TI juga dapat meningkatkan risiko negatif terhadap tujuan sebuah perusahaan. dan Dimana ketergantungan perusahaan terhadap TI akan semakin memperbesar dampak risiko terhadap perusahaan. Risiko yang telah timbul akan berpengaruh proses 
kerja yang tidak optimal, kerugian finansial, menurunnya kualitas perusahaan hingga tidak tercapainya tujuan dari perusahaan.

Mobile banking merupakan sebuah layanan yang telah disediakan oleh bank untuk melakukan berbagai transaksi perbankan melalui berbagai fitur yang ada pada ponsel pintar (smartphone). Salah satu perusahaan ini sudah menerapkan TI dan Software yang saat ini digunakan di BANK BNI KCP PENAJAM yaitu ERP. Sistem ini berbasis ERP. Proses bisnis pada Perusahaan ini telah mengacu pada standar ISO 27001 di mana ISO ini menjadi jaminan keamanan data nasabah dengan berstandar Big Data yang merujuk pada istilah data yang besar dan bergerak cepat mapun kompleks sehingga metode proses data tradisional tidak dapat mengolah data tersebut lagi.

Macam-macam dari risiko cukup beragam dan hampir semua aktivitas pada perusahaan telah memiliki risiko tersendiri. Sehingga perlu untuk dilakukannya sebuah identifikasi, monitoring dan evaluasi terhadap risiko. Belum ada inilah manajemen risiko yang akan membuat pengendalian risiko dilakukan dengan cara yang sering dilakukan atau dengan mengacu pada kebiasaan ketika menangani risiko yang sama. Belum ada dokumen standar pada prosedur untuk menangani risiko, sehingga penanganan risiko belum di manage dengan baik.

Mobile Banking atau yang dikenal dengan M-Banking ini merupakan salah satu produk dari layanan perbankan yang berbasis teknologi informasi. Menurut Riswadi (2005) pengertian mobile banking yaitu sebuah fasilitas atau layanan perbankan menggunakan alat komunikasi bergerak seperti handphone, dengan penyediaan fasilitas untuk bertransaksi perbankan melalui aplikasi handphone. Dengan adanya layanan mobile banking, transaksi perbankan yang biasanya dilakukan secara manual, artinya kegiatan yang sebelumnya dilakukan nasabah dengan mendatangi bank, sekarang dapat dilakukan tanpa harus mengunjungi gerai bank, hanya dengan menggunakan handphone nasabah dapat menghemat waktu dan biaya.

M-Banking BNI adalah layanan untuk melakukan berbagai transaksi yang ditawarkan bank. Karena telah berbentuk aplikasi, kamu harus mengunduh layanan mobile ini pada smartphone. Dan Untuk pendaftarannya, bisa dilakukan dengan sendiri dan mengikuti langkah-langkah yang ada pada aplikasi tersebut. Jika belum jelas, kamu bisa menghubungi customer service di bank terdekat . Kita tidak perlu repot-repot untuk keluar rumah buat ke ATM atau ke bank untuk menyelesaikan transaksi keuangan, seperti berbelanja, transfer uang, hingga bayar kebutuhan hidup.

Dengan semakin banyaknya Bank umum maupun banyaknya tersedianya layanan M-Banking persaingan antar bank semakin ketat, sehingga memunculkan pertanyaan yang mendasar apakah semua kondisi bank tersebut memiliki risiko atau tidak, serta didalam proses bisnisnya, apakah informasi yang didapat sudah akurat dan terintegrasi, dikarenakan pada data yang diolah pada Bank BRI sangatlah banyak, seperti data nasabah, data jaminan kredit, laporan keuangan 
dan lain-lain. Kebutuhan akan informasi merupakan hal yang penting bagi stakeholder (dalam hal ini kreditur, debitur, komisaris, direksi, karyawan dan pihak-pihak lain yang berkepentingan), oleh karena itu Bank BRI harus menerapkan teknologi informasi yang tepat sehingga mampu memberikan pelayanan terbaik bagi nasabahnya.

Pada BANK BNI Cabang Penajam, belum terdapat tim khusus untuk mengelola risiko yang dapat terjadi terkait TI pada pengelolaan M-Banking BNI Oleh sebab itu maka sangat diperlukan adanya evaluasi pengelolaan risiko Teknologi Informasi (TI) dimana pada penelitian ini, menggunakan framework COBIT 5 (Control Objectives for Information and Related Technology) untuk mengetahui tingkat kapabilitas yang telah dicapai guna untuk meningkatkan kemampuan perusahaan dalam menerapkan manajemen risiko Teknologi Informasi (TI). Karena framework COBIT 5 ini merupakan salah satu kerangka kerja yang banyak digunakan pada TI Governance yang mendukung keselaarasan TI dengan bisnis. APO12 (Manage Risk) ini Bertujuan untuk mengidentifikasi, menilai dan mengurangi risiko yang terkait dengan TI agar tidak melebihi batas toleransi yang telah ditentukan oleh organisasi. Dalam mengintegrasikan manajemen risiko TI dengan manajemen risiko perusahaan (ERM). Salah satu pengukuran yang dilakukan dalam penggunaan COBIT 5 yaitu pengukuran tingkat kapabilitas (capability level) yang memfokuskan pada subdomain EDM03 (Ensure Risk Optimisation).

\section{Metode Penelitian}

\section{Metode Pengumpulan Data}

Kuesioner

Pada tahap kuesioner penulis membuat daftar pertanyaan yang harus diisi atau dijawab oleh responden serta orang sekitar yang akan dimintai keterangan. Kuesioner dilakukan terhadap 10 pegawai dan masyarakat pengguna m-banking bri dan mengenai tingkat kapabilitas proses (Process Capability Level), yang bertujuan untuk mengetahui tingkat kapabilitas pada proses pengelolaan manajemen risiko pada teknologi informasi mbanking bri. Responden pada kuesioner memiliki pengukuran tingkat kapabilitas adalah pihak-pihak yang terdapat pada struktur RACI Chart dari proses APO12 (Manage Risk).

\section{Metode Analisis}

A. Metode Perhitungan Skala Likert

Skala penelitian yang digunakan ini untuk mengukur sikap dan pendapat. Dengan skala likert ini, para responden diminta untuk melengkapi kuesioner yang mengharuskan mereka untuk menunjukkan tingkat persetujua mereka terhadap serangkaian pertanyaan. Dan untuk menghitung total skor tiap responden adalah dengan cara menjumlahkan 
skor-skor item yang diperoleh responden. Pada persamaan merupakan rumus yang digunakan dalam perhitungan skala Likert: Rumus rata-rata Persentase.

\section{Rata-Rata Persentase} kuesioner.

$$
=\left[\frac{\Sigma(n \times \text { bobot nilai })}{\Sigma \text { Total Responden }}\right] \times 100 \%
$$

$\mathrm{N}$ adalah total jawaban dari responden berdasarkan kriteria jawaban

Sedangkan pada persamaan merupakan rumus mencari \% nilai rata - rata proses atribut (PA) kuesioner

\section{Rata-Rata PA}

$$
=\left[\frac{\sum \text { Persentase tiap kriteria PA }}{\text { Jumlah Kriteria PA }}\right]
$$

Berikut adalah hasil perhitungan dari kuesioner yang telah dilakukan:

1. Pada Setiap level memiliki beberapa proses atribut (PA). Pada setiap proses atribut terdapat beberapa kriteria yang harus dipenuhi sesuai standar pemenuhan proses atribut ini dalam COBIT 5.

2. Masing masing kriteria yang memiliki rentang nilai $N \quad P \quad L F$. Nilai tersebut akan merepresentasikan tingkat pencapaian yang telah dicapai dari masing-masing kriteria.

3. Setiap rentang nilai memiliki bobot penilaiannya.

4. Dari setiap kriteria ini kemudian dilakukan pengelompokan berdasarkan jawaban per pertanyaan dan per kriteria rentang yang dicapai.

5. Menambahkan jumlah responden telah sesuai dengan rentang nilai lalu dikali dengan bobot.

6. Hasil penjumlahan kemudian dibagi terhadap jumlah responden dan penilaian lalu dikalikan dengan $100 \%$.

7. COBIT 5 ini memberikan rating levels dan Dari hasil tersebut didapatkan hasil akhir yang kemudian dapat dikategorikan sesuai aturan:

a. $\mathrm{N}$ (Not Achieved, range $0 \%$ sampai 15\%), tidak terdapat atau hanya sedikit bukti terhadap suatu pencapaian atribut yang ada pada proses tersebut. Range nilai yang diperoleh di kategori ini berkisar antara $0 \%$ sampai $15 \%$.

b. P (Partically Achieved, range>15\% sampai 50\%), didapatkan beberapa bukti bahwa terkait pendekatan dan pencapaian atribut atas proses tersebut. Dan Range nilai yang diperoleh di kategori ini berkisar antara $>15 \%$ sampai $50 \%$.

c. L (Largely Achieved, range $>50 \%$ sampai 85\%), terdapat bukti atas pendekatan yang sistematis dan pencapaian signifikan atas proses tersebut, meskipun masih terdapat beberapa kelemahan yang tidak 
signifikan. Range nilai yang diraih pada kategori ini berkisar antara $>50 \%$ sampai $85 \%$.

d. (Fully Achieved, range $>85 \%$ sampai 100\%), terdapat bukti atas pendekatan sistematis dan lengkap serta pencapain penuh terhadap atribut proses tersebut dan tidak ada kelemahan terkait atribut dari proses tersebut. Range nilai yang diraih pada kategori ini berkisar antara $>85 \%$ sampai $100 \%$.

\section{Hasil dan Pembahasan}

a. Hasil Kusioner

Dari penjelasan tersebut didapati hasil kapabilitas yang diperoleh berada di Level 1 Performed Process dengan perolehan nilai sebesar 82,04\% dengan status Largely Achieved. Status ini menjelaskan bahwa pengelolaan risiko pada Teknologi Informasi di M-banking BRI telah mencapai tujuan prosesnya namun hasil proses pengelolaan masalah belum tercapai sepenuhnya. Target yang diharapkan adalah level 2 Managed Process untuk menentukan nilai kesenjangan (GAP).

b. Hasil Capability Level

Dan untuk hasil perhitungan atau penilaian capability level dapat dilihat pada Tabel berikut yang menunjukkan bagaimana perhitungan untuk masing-masing domain,
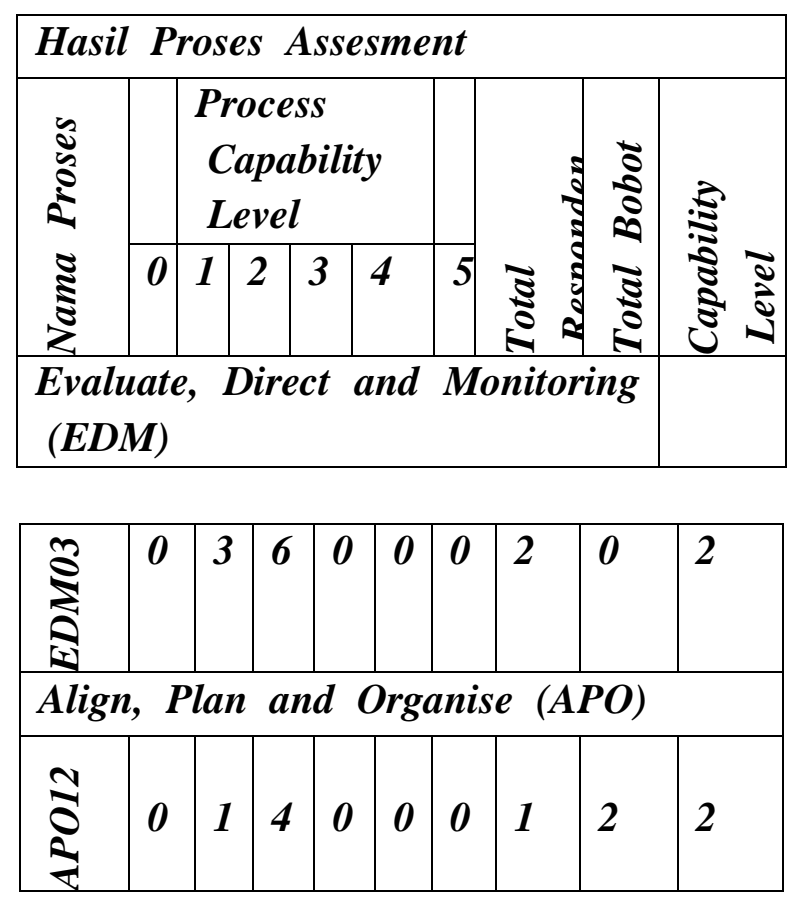

Tabel 1. Hasil Penilaian Capability Level 
Analisis Tingkat Kapabilitas Proses (Process Capability Level) Analisis tingkat kapabilitas ini berdasarkan hasil kuesioner tentang tata kelola teknologi informasi terkait pengelolaan risiko pada pada m-banking bri yang mengacu pada COBIT 5 menggunakan Subdomain APO12 (Manage Risk) Responden yang dibutuhkan untuk analisa ini sesuai dengan RACI Chart COBIT 5 dengan menggunakan Subdomain APO12.

c. Analisis GAP

Berdasarkan hasil perhitungan dari proses APO12 yang menjadi acuan dalam evaluasi pengelolaan risiko di Bank BNI Cabang Penajam, perolehan tingkat kapabilitas saat ini berada di level 1 (Performed Process) dengan perolehan nilai 79,10\%. Target yang ingin dicapai adalah level 2 (Managed Process). Karena jika ingin mencapai level lain, harus meningkatkan status di level 2 menjadi Largerly ataupun Fully Achieved. Status Fully Achieved dicapai dengan range $>85 \%$ (dalam tabel diasumsikan nilai $88,08 \%$ sebagai batas bawah pencapaian). Hasil analisis kesenjangan tersebut akan diperoleh dengan melihat selisih antara nilai yang sudah diterapkan saat ini dengan nilai yang diharapkan, akan diperjelas dengan menggunakan tabel 2 berikut:

\begin{tabular}{|c|c|c|c|c|}
\hline $\begin{array}{l}\text { Proses } \\
\text { Atribu } \\
\mathbf{t}\end{array}$ & $\begin{array}{l}\text { Nilai } \\
\text { Saat } \\
\text { ini }\end{array}$ & $\begin{array}{l}\text { Nilai } \\
\text { yang } \\
\text { diinginka } \\
\text { n }\end{array}$ & GAP & Penjelasan \\
\hline PA 1.1 & $82,4 \%$ & $88,08 \%$ & $\begin{array}{l}79,10 \\
\%\end{array}$ & $\begin{array}{l}\text { Kesenjangan cukup besar yang artinya } \\
\text { tujuan dan hasil proses pengelolaan } \\
\text { risiko belum sepenuhnya tercapai. } \\
\text { Dimana proses penetapan kerangka kerja } \\
\text { manajemen risiko namun belum sejalan } \\
\text { dengan kerangka kerja manajemen risiko } \\
\text { organisasi, analisis risiko belum } \\
\text { maksimal dan tidak adanya catatan } \\
\text { mengenai kejadian }\end{array}$ \\
\hline $\begin{array}{c}\text { Process } \\
\text { Perfor } \\
\text { mance }\end{array}$ & & & & risiko yang berhubungan dengan TI \\
\hline
\end{tabular}

Tabel 2. Analisis Kesenjangan Proses Atribut level 1\&2 
Dasar proses manajemen risiko pada COBIT 5 memiliki dua subdomain proses, yaitu EDM03 (Ensure Risk Operation) dan APO12 (Manage Risk).

Berikut mengenai penjelasan dari masing - masing proses menurut ISACA:

1. EDM03 Ensure Risk Optimisation

Proses ini berisi tentang pemahaman, artikulasi dan komunikasi dari risk appetite perusahaan dan bagaimana toleransi untuk menyikapi, serta memastikan proses identifikasi dan manajemen risiko terhadap nilai perusahaan yang terkait dengan. Domain EDM03 memiliki 3 bagian domain atau subdomain proses yaitu sebagai berikut:
a. EDM03.01 Evaluate Risk Management
b. EDM03.02 Direct Risk Management
c. EDM03.03 Monitor Risk Management

2. APO12 Managed Risk

Proses domain ini meliputi identifikasi secara terus menerus, dengan melakukan penilaian dan pengurangan risiko yang berkaitan dengan TI dalam tingkat toleransi yang telah ditetapkan oleh pihak manajemen eksekutif perusahaan. Domain APO12 memiliki 6 subdomain yaitu sebagai berikut:
a. APO12.01 Collect Data
b. APO12.02 Analyse Risk
c. APO12.03 Maintain A Risk Profile
d. APO12.04 Articulate Risk
e. APO12.05 Define a Risk Management Action Portofolio
f. APO12.06 Respond to Risk

Dari domain ini dilakukan penilaian capability level yang bertujuan untuk memberikan penilaian yang berbeda dari satu level ke level yang lebih tinggi. Penilaian dilakukan dimulai dari level terendah yaitu level 1. Level kapabilitas proses yang digunakan di dalam penilaian proses terdiri dari enam level yaitu:

1. Level 0: incomplete process, yaitu proses tidak diimplementasi atau gagal mencapai tujuan proses. Terdapat sedikit atau tidak ada bukti pencapaian tujuan proses secara sistematis

2. Level 1: performed process, yaitu implementasi proses mencapai tujuannya. Atribut proses yang mencerminkan pencapaian level ini adalah PA1.1 process performance. PA 1.1 mengukur sampai sejauh mana tujuan proses dicapai. Hasil pencapaian atribut ini tercermin dari setiap proses menghasilkan keluaran yang diharapkan

3. Level 2: managed process, yaitu proses pada level 1 diimplementasi ke dalam sebuah pengaturan proses (direncanakan, dimonitor, dan dievaluasi) dan produk kerja proses tersebut ditetapkan, dikontrol, dan dipertahankan secara tepat. Atribut yang terdapat pada level ini adalah 
a. PA 2.1 performance management: mengukur sampai sejauh mana pelaksanaan proses diatur.

b. PA2.2 work product management: mengukur sampai sejauh mana produk kerja diproduksi oleh proses yang telah diatur dengan baik.

4. Level 3: Established process, yaitu proses pada level 2 diimplementasi menggunakan proses yang terdefinisi dan mampu mencapai hasil proses. Atribut yang terdapat pada level ini adalah :

- PA3.1 process definition : mengukur sejauh mana proses didefinisikan untuk mendukung pelaksanaan proses.

- PA3.2 process deployment : mengukur sejauh mana standar proses dilaksanakan secara efektif.

5. Level 4 : predictable process, yaitu proses pada level 3 dijalankan dengan batasan yang telah terdefinisi untuk mencapai hasil proses. Atribut yang terdapat pada level ini adalah :

- PA4.1 process measurement : mengukur sejauh mana hasil pengukuran digunakan untuk menjamin pelaksanaan proses dapat mendukung pencapaian tujuan organisasi.

- PA4.2 process control : mengukur sejauh mana proses diatur secara kuantitatif untuk menghasilkan sebuah proses yang stabil dan dapat diprediksi sesuai dengan batasan yang didefinisikan.

6. Level 5 : optimizing process, yaitu proses pada level 4 ditingkatkan secara berkelanjutan untuk memenuhi tujuan organisasi saat ini dan saat mendatang. Atribut yang terdapat pada level ini adalah

- PA5.1 process innovation : pengukuran sejauh mana perubahan proses diidentifikasi dari pelaksanaan proses dan dari pendekatan inovasi terhadap pelaksanaan proses.

- PA5.2 process optimization : mengukur sejauh mana perubahan didefinisikan, mengelola pelaksanaan proses secara efektif untuk mendukung pencapaian tujuan peningkatan proses.

\section{Kesimpulan}

Dari hasil penelitian yang telah dilakukan pada M-Banking BNI KCP Penajam terhadap proses pengelolaan risiko teknologi informasi yang diterapkan saat ini, maka dapat dikesimpulan bahwa tingkat kapabilitas pada kegiatan proses pengelolaan risiko saat ini masih berada pada level 1 (Performed Process) PA 1.1 Process Performance dengan status Largerly Achieved yaitu dengan nilai $79,10 \%$ GAP. Dengan demikian status tersebut telah memiliki bukti dan juga pendekatan secara sistematis serta pencapaian secara signifikan yang diperoleh melalui penilaian pada proses atribut. Meskipun masih ada banyak kelemahan yang ada pada proses tersebut. 


\section{Bibliografi}

S. D. N,Supratno, Kusyanti.E," Evaluasi Manajemen Risiko Teknologi Informasi Menggunakan Framework COBIT 5 (Studi Kasus : PT. Kimia Farma (Persero) Tbk - Plant Watudakon) Jurnal Pengembangan Teknologi Informasi dan Ilmu Komputer, Vol.2, No.1, hlm. 143-152, 2018.

M.Habibullah Arief, Suprapto, "Evaluasi Manajemen Risiko Teknologi Informasi Menggunakan Kerangka Kerja Cobit 5(Studi Kasus Pada Perum Jasa Tirta I Malang), Jurnal Pengembangan Teknologi Informasi dan Ilmu Komputer, Vol.2, No.1, hlm. 101-110, 2018.

Nurfitri Zukhrufatuk Firdaus, Suprapto. "Evaluasi Manajemen Risiko Teknologi Informasi Menggunakan COBIT 5 IT Risk (Studi Kasus : PT.Petrokimia Gresik)." Jurnal Pengembangan Teknologi Informasi dan Ilmu Komputer, Vol.1, No.1, hlm. x-x, 2017.

A. D. M.,. A. S. Fransisca Tiarawati Riadi, "Evaluasi Manajemen Risiko Keamanan Informasi Dengan Menggunakan COBIT 5 Subdomain EDM03 (Ensure Risk Optimisation) (Studi Kasus: Satuan Organisasi XYZ - Lembaga ABC)," JUTEI, vol. 2, no. 1, pp. 2579-3675, 2018.

Putri . E . R, "Penilaian Kapabilitas Proses Tata Kelola TI Berdasarkan Proses DSSO1 Pada Framework COBIT 5," jurnal CoreIT,vol.2, no.1, 2016

S . W, I. G, Destya. K., "Evaluasi Pengelolaan Risiko Teknologi Informasi Menggunakan Framework COBIT 5 Berdasarkan Domain APO12 (Manage Risk) pada Kantor Pusat BPR Agung Sejahtera," Jurnal of information system, vol. 5, no. 1, pp. 18-26, 2020.

R. Novi, W.A.R. Yudi. "Pengaruh Minat Individu Terhadap Penggunaan Mobile Banking (M-Banking): Model Kombinasi Technology Acceptance Model (Tam) Dan Theory Of Planned Behavior (Tpb)", jurnal informasi. Vol.7 , No.1 , mei 2017

U. Zazinul, Pengelolaan Manajemen Risiko Layanan Mobile Banking Pada Bank Rakyat Indonesia (Bri) Syariah Kcp Purwodadi, skripsi Fakultas Ekonomi Dan Bisnis Islam, UIN Walisongo semarang, 2019. 